\title{
EFEK BALANCE EXERCISE TERHADAP KEKUATAN OTOT PADA LANSIA POST STROKE
}

\author{
Ayuhana Sriwaharti ${ }^{1^{*}}$, Achmad Fauzi ${ }^{2}$ \\ 1. Program Studi S1 Keperawatan, STIKes Kesetiakwanan Sosial Indonesia, Bekasi-Indonesia \\ 2. Program Studi Profesi Ners, STIKes Kesetiakwanan Sosial Indonesia, Bekasi-Indonesia
}

*Korespondensi: Ayuhana Sriwaharti | STIKes Kesetiakwanan Sosial Indonesia | ayuhanasri@gmail.com

\begin{abstract}
Abstrak
Pendahuluan: Post stroke pada lansia berdampak pada gangguan fungsi kognitif dan efek psikologis. Selain itu juga akan mempengaruhi berbagai defisit neurologik. Tanda dan gejala stroke berupa gangguan motorik. Salah satu upaya untuk peningkatan kekuatan otot adalah melakukan gerakan balance exercise yang dilakukan selama 5 minggu dengan frekuensi tindakan setiap 3 kali dalam satu minggu. Tujuan penelitian untuk mengetahui pengaruh balance exercise terhadap kekuatan otot pada lansia post stroke.

Metode: Penelitian ini menggunakan One Group Pre-Post Test Design dengan analisa data uji T dependen untuk data bivariat, dan distribusi frekuensi untuk data univariat sebelum dan setelah pemberian balance exercise.

Hasil: Dari 13 orang yang menjadi responden, semuanya mengalami penurununan kekuatan otot. Kekuatan otot sebelum diberikan intervensi sebesar 2.38 dan setelah diberikan intervensi terjadi peningkatan kekuatan otot sebesar 3.62 dengan Pvalue $<0.000$.
\end{abstract}

Kesimpulan: Balance Exercise efektif dalam meningkatkan kekuatan otot pada lansia post stroke.

Kata Kunci: Balance exercise, Kekuatan otot, Lansia, Pasca stroke.

Diterima 8 Februari 2021; Accepted 30 Juni 2021

\section{PENDAHULUAN}

Lansia adalah suatu keadaan dalam tahap lanjut dari proses kehidupan ditandai terjadinya ya penurunan fisiologis yang mempengaruhi system keseimbangan diantaranya system muskoloskeletal (penurunan jumlah dan serabut otot) (Pujiastuti, 2003). Akibat dari hal tersebut maka akan terjadi penurunan kekuatan otot ekstermitas bawah (Darmojo, 2011). Kekuatan otot ekstremitas bawah akan berkurang sebesar 40\% antara usia 30 sampai 80 tahun sehingga dapat menyebabkan terjadinya gangguan keseimbangan (Arifal \& Kharisma, 2018).

Tidak hanya penurunan kekuatan otot, beberapa penyakit juga mengakibatkan gangguan gerak pada sistem muskuloskeletal salah satunya stroke (Sufiya, Herawati, \& Fis, 2017). Stroke berdampak pada gangguan fungsi kognitif dan efek psikologis selain itu juga akan memengaruhi berbagai defisit neurologik, tanda dan gejala stroke berupa gangguan motorik. Defisit neurologis yang disebabkan oleh cedera fokus akut dari sistem saraf pusat (SSP) oleh penyebab vaskular, termasuk infark serebral, perdarahan intraserebral dan perdarahan subarachnoid (Ramdani, 2018). Stroke dapat menyebabkan paralisis di berbagai tingkat, kesulitan berbicara, kehilangan memori atau kemampuan dalam penalaran, koma atau bahkan kematian (Ramdani, 2018).

Prevalensi penyakit kronik di seluruh dunia semakin meningkat, salah satunya di Indonesia. Stroke merupakan penyebab kematian terbanyak kedua setelah Ischemic Heart Disease, dengan usia penderita lebih dari 60 tahun (Noor, 2018). Angka kejadian stroke di dunia sekitar 200 per 100.000 penduduk dalam setahun (Widarti \& Triyono, 2018). Data diagnosa stroke di Indonesia pada penduduk usia kurang lebih 15 tahun sebanyak 10,9\%, di provinsi Kalimantan Timur menempati urutan tertinggi sebanyak 14,7\% sedangkan provinsi Papua urutan terendah sebanyak 4,1\% (Badan Penelitian dan Pengembangan Kesehatan Kementerian Kesehatan RI, 2018). Salah satu Panti Sosial Tresna Werdha di kota Jakarta yaitu PSTW Budi Mulia 2 Cengkareng Jakarta Barat mencatat angka kejadian pasca stroke sebanyak 24 lansia dari 334 lansia di panti tersebut. Setiap tahun jumlah ini mengalami kenaikan sebanyak $2-5$ lansia. Untuk lansia pasca stroke cenderung memiliki gejala sisa yang dapat mempengaruhi fungsi fisik seperti kehilangan motorik dan aktivitas sehari-hari (Arianti, Novera, \& Restipa, 2019).

Terdapat beberapa Intervensi yang meningkatkan fungsi fisik dalam keseimbangan dan kekuatan otot seperti latihan Balance board Exercise. Latihan ini merupakan suatu aktivitas fisik yang dilakukan untuk meningkatkan kestabilan tubuh dengan cara meningkatkan kekuatan otot ekstremitas bawah menggunakan 
sebuah alat papan keseimbangan yang digunakan untuk melatih propioceptif ekstrimitas atas atau bawah (Haryani, Fatmawati, \& Imron, 2016). Latihan exergames adalah latihan dengan cara bermain seperti memperagakan tarian pada sebuah video permainan untuk latihan fisik selama 150 menit dalam satu minggu (Costa et al., 2019).

Balance exercise (latihan keseimbangan) adalah latihan khusus yang bertujuan untuk meningkatkan kekuatan otot melalui serangkaian gerakan yang dilakukan untuk meningkatkan keseimbangan, baik statis maupun dinamis. Gerakan ini dilakukan melalui stretching dan strengthening. Selain itu balance exercise juga bertujuan untuk membantu meningkatkan kekuatan otot pada anggota gerak bawah dan sistem vestibular atau keseimbangan tubuh untuk mengurangi resiko terjadinya jatuh pada lansia. Balance exercise merupakan intervensi perawat mandiri yang tepat dan mudah dilakukan pada lansia pasca stroke yang telah mengalami gangguan keseimbangan dan penurunan kekuatan otot kapan saja. Tanpa adanya sertifikat khusus laitihan ini tetap bisa dilakukan. Untuk observasi keseimbangan balance exercise dapat menggunakan Berg Balance Scale sedangkan untuk kekuatan otot menggunakan muscle strength scale. Observasi ini dilakukan sebelum dan setelah balance exercise (Arifal \& Kharisma, 2018). Ada beberapa gerakan yang digunakan dalam balance exercise, seperti gerakan plantar fleksi, hip fleksi, hip ekstensi, knee fleksi, side leg rise.

Program Balance exercise untuk meningkatkan keseimbangan postural dilakukan dengan frekuensi 3 kali seminggu selama 5 minggu (Arifal \& Kharisma, 2018). Latihan dilakukan selama 25 menit, dengan pemanasan 5 menit, dan latihan 20 menit. Persiapan yang dilakukan terdiri dari dua persiapan yaitu persiapan tempat dan klien. Persiapan tempat dapat dilakukan di wisma tempat tinggal lansia, sedangkan persiapan klien berupa memberi salam dan perkenalan diri, mengidentifikasi identitas. klien, menjelaskan tujuan tindakan intervensi, menjelaskan Langkah-langkah intervensi yang akan dilakukan, menjelaskan lama intervensi, mengatur tempat dan kenyamanan posisi klien.

\section{METODE}

Penelitian ini dilakukan dengan desain Quasi Eksperimental One Group pre-post test design. Penelitian dilaksanakan pada bulan Maret - Mei 2019. Populasi penelitian adalah lansia pasca stroke yang mengalami gangguan kelemahan otot di PSTW Budi Mulia 2 Cengkareng. Sampel ditentukan dengan teknik purposive sampling berdasarkan pemenuhan inklusi peneliti. Kriteria inklusi meliputi; kesadaran composmentis, lansia yang mengalami gangguan kelemahan otot, pasien pasca stroke dengan gangguan kelemahan otot sebelum diberikan balance exercise, dan bersedia menjadi responden. Sedangkan kriteria eksklusi meliputi; responden mengalami cedera anggota gerak bawah dalam 1 tahun terakhir, responden tidak mengikuti latihan 3 kali berturut-turut, dan responden tidak melanjutkan program latihan. Jumlah sampel yang diperoleh sesuai kriteria inklusi sebanyak 13 responden. Variabel yang diteliti meliputi; jenis kelamin, usia, lamanya pasca stroke, kekuatan otot sebelum intervensi dan kekuatan otot setelah intervensi. Variabel jenis kelamin, usia dan lamanya stroke dianalisa secara univariat. Variabel kekuatan otot sebelum dan sesudah intervensi dianalisa secara bivariat menggunakan uji statistik dependent sample T-test (SPSS ver 22). Alat dan bahan yang digunakan yaitu: data demografi meliputi nama, jenis kelamin, usia, lama pasca stroke, muscle strength scale yaitu kuisioner untuk mengidentifikasi skala kekuatan otot, dan stopwatch untuk menghitung durasi selama dilakukannya balance exercise.

Tahapan penelitian meliputi, persiapan, pelaksanaan dan pengolahan data. Tahap persiapan dilakukan dengan mengidentifikasi responden sesuai kriteria inklusi, selanjutnya responden mengisi informed consent lalu melengkapi data kuisioner berupa data demografi, dan lembar observasi muscle strength scale. Tahap pelaksanaan dilakukan dengan memberikan intervensi pada responden (lansia) yang melakukan balance exercise menggunakan bantuan kursi selama kurang lebih 90 detik untuk tiap sesi gerakan. Intervensi dilakukukan selama 3 kali seminggu, selama 5 minggu. Setelah intervensi dilakukan pengukuran kekuatan otot menggunakan lembar observasi muscle strength scale. Tahap akhir adalah pengolahan data yang meliputi pengecekan isian kuisioner, dilanjutkan dengan coding dan entry data ke dalam program analisis uji statistik. Penelitian ini sudah dinyatakan lolos etik dengan nomor 02/Ethical Clearence/STIKesKesosi/VII/2019.

\section{HASIL}

Responden pada penelitian adalah sebanyak 13 orang, sebagian besar berjenis kelamin laki-laki (69.2\%). Dari semua responden, paling banyak mengalami pasca stroke kurang dari 6 tahun $(53,8 \%)$ (Tabel 
1). Rata-rata umur responden pada intervensi adalah 63.75 tahun dengan standar deviasi 11.71. Usia termuda pada penelitian ini yaitu 46 tahun sedangkan usia yang tertua adalah 81 tahun. Dari hasil estimasi interval dapat disimpulkan pada 95\% CI diyakini bahwa rata-rata usia responden pada kelompok intervensi adalah antara 56.31 sampai dengan 71.19 tahun (Tabel 2). Variable pengukuran baseline pada metode balance exercise pada pengukuran skala kekuatan otot post test memiliki nilai uji Shapiro wilk sebesar 0.105 , karena nilai $\mathrm{P}>0.05$ (lebih besar dari nilai alpha), maka H0 diterima, artinya variable pengukuran baseline menyebar mengikuti distribusi normal (Tabel 3).

Tabel 1. Distribusi frekuensi karakteristik responden pasca stroke yang mengalami perubahan skala kekuatan otot atau atau muscle strength scale di PSTW Budi mulia 2 Cengkareng tahun $2019(\mathrm{n}=13)$

\begin{tabular}{ccc}
\hline Karakteristik & Frequency & Percent (\%) \\
\hline Jenis kelamin & & \\
1. Laki-laki & 9 & 69.2 \\
2. Perempuan & 4 & 30.8 \\
Lama post stroke & & \\
1. $<6$ tahun & 7 & 53.8 \\
2. $>6$ tahun & 6 & 46.2 \\
\hline
\end{tabular}

Tabel 2. Analisis kesetaraan usia pada responden pasca stroke yang mempengaruhi kekuatan otot di PSTW Budi Mulia 2 Cengkareng $(n=13)$

\begin{tabular}{cccccc}
\hline Variabel & Mean & Median & SD & Min-Maks & 95\% CI \\
\hline Usia Intervensi & 63.75 & 65.00 & 11.71 & $46-81$ & $56.31-71.19$ \\
\hline
\end{tabular}

Tabel 3. Hasil uji normalitas kekuatan otot pada pengukuran pre test dan post test pada intervensi balance exercise pada responden pasca stroke stroke di PSTW Budi Mulia 2 Cengkareng tahun 2019 (n=13)

\begin{tabular}{ccc}
\hline Pengukuran & Kategori & Shapiro-Wilk Sig \\
\hline Pre test & Skala kekuatan otot & 0.116 \\
Post test & Skala kekuatan otot & 0.105 \\
\hline
\end{tabular}

Tabel 4. Pengaruh balance exercise terhadap kekuatan otot pada pasien pasca stroke di PSTW Budi Mulia

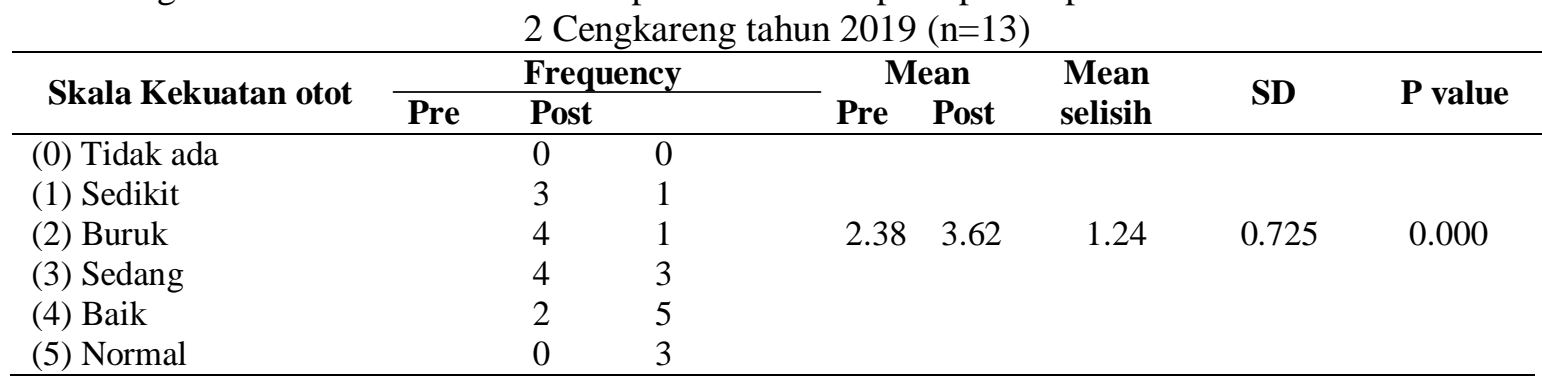

Hasil analisis kondisi kekuatan otot setelah mendapatkan terapi balance exercise terjadi peningkatan kekuatan otot menjadi baik 38.5\%. Hasil analisa rata-rata menunjukkan bahwa kondisi kekuatan otot pada responden pasca stroke yang mendapatkan balance exercise meningkat secara bermakna sebesar 1.24 dengan $P$ value $=0,000(\mathrm{P}<0.05)$ Berdasarkan data diatas dapat disimpulkan bahwa terjadi perubahan bermakna kondisi kekuatan otot sebelum dan setelah intervensi balance exercise (Tabel 4).

\section{PEMBAHASAN}

Dari hasil penelitian dapat disimpulkan bahwa laki-laki memiliki resiko terjadinya perubahan kekuatan otot lebih besar dibandingkan dengan perempuan. Hal tersebut sesuai dengan teori yang mengungkapkan bahwa serangan stroke lebih banyak terjadi pada laki-laki dibandingkan perempuan (Goldstein et al, 2006). Jenis kelamin laki-laki berpengaruh terhadap kejadian stroke, hal ini dilihat dari gaya hidup laki-laki yang banyak merokok, minum alkohol (Watila dkk, 2010). Karena zat yang terkandung dalam rokok seperti 
nikotin dapat menyebabkan kerusakan dinding pembuluh darah, yang menyebabkan elastisitas darah berkurang sehingga meningkatkan pengerasan pembuluh darah arteri dan meningkatkan faktor pembekuan darah karena kadar fibrinogen darah yang tinggi. Peningkatan kadar fibrinogen ini mempermudah terjadinya penebalan pembuluh darah sehingga pembuluh darah menjadi sempit dan kaku yang memicu terjadinya stroke (Sari, 2016). Dilihat dari penelitian sebelumnya menurut Wayunah dan Saefulloh (2017) hasil penelitian menunjukkan bahwa jenis kelamin terbanyak yaitu laki-laki sebanyak 76 responden atau 73.8\% dengan jumlah 103 responden. Sedangkan untuk hasil penelitian jenis kelamin mempengaruhi terjadinya stroke yang didukung oleh Zhang, Chapman, Plested, Jackson, dan Purroy (2012) yang menunjukkan bahwa laki-laki mempunyai risiko 0,95 kali lebih besar terkena stroke dibandingkan perempuan. Hasil penelitian ini serupa dengan hasil penelitian sebelumnya bahwa pada jenis kelamin lakilaki mempunyai risiko sebesar 4,37 kali terkena stroke. Jenis kelamin laki-laki cenderung lebih berisiko terkena stroke karena perempuan cenderung mengalami stroke pasca menopause. Hasil studi kasus, lakilaki cenderung terkena stroke 3 kali berisiko dibanding dengan perempuan (Mahendra \& Rachmawati, Evi, 2014).

Berdasarkan penelitian ini didapatkan hasil bahwa lamanya pasca stroke terbanyak pada intervensi yaitu $<6$ tahun sejumlah 7 orang dan sisanya $>6$ tahun sejumlah 6 orang dengan persentase secara berturut-turut yaitu $53.8 \%$ dan $46.2 \%$. Lamanya pasien yang mengalami pasca stroke tentu akan mempengaruhi keluhan yang ditimbulkan. Hal tersebut berpengaruh karena pada lansia yang sudah lebih lama mengalami pasca stroke akan mengalami keterbatasan aktivitas, dimana hal itu juga sama-sama ikut dipengaruhi oleh faktor yang lebih dominan seperti tidak melakukan streching statis dan dinamis.

Hasil penelitian menunjukkan rentang usia responden yang dilakukan intervensi berada pada rentang 46 sampai 81 tahun dengan rata-rata 63.75 tahun, dimana menurut World Health Organization (WHO) 63.75 tahun masuk ke dalam golongan lanjut usia atau elderly yang berkisaran 60-74 tahun. Berdasarkan data dalam penelitian sebelumnya yang berjudul "faktor-faktor yang berhubungan dengan terjadinya stroke berulang pada penderita pasca stroke" menjelaskan bahwa mayoritas penderita stroke berulang adalah usia 60-69 tahun, hasil penelitian tersebut menunjukkan distribusi berdasarkan mayoritas usia lanjut (Sari, 2016). Hasil penelitian ini sesuai dengan teori tersebut dimana rata-rata usia lansia pasca stroke pada intervensi ini adalah di bawah 65 tahun. Hal ini disebabkan semakin meningkatnya usia maka sistem pembuluh darah mengalami pemunduran sehingga berisiko mengalami stroke. Hasil penelitian Noor (2018) juga menyebutkan bahwa rata-rata usia post stroke adalah 60.97 tahun, Dari hasil penelitiannya dimana semakin bertambah umur semakin meningkat risiko stroke dan hal ini berkaitan dengan terjadinya proses degenerasi serta dinding pembuluh darah juga lebih mudah mengalami penebalan (arterosklerosis).

Hasil dalam penelitian ini untuk pre intervensi balance exercise pada lansia pasca stroke mengalami penurunan atau gangguan kekuatan otot, dengan jumlah responden $(n=13)$ sebesar $2.38 \%$ dimana sebelumnya kekuatan otot 1: sedikit (3 lansia) dan kekuatan otot 5: normal (0 lansia). Hal ini dipengaruhi oleh lansia yang terlalu lama menderita post stroke yaitu antara $>6$ tahun, selain itu juga dipengaruhi oleh usia lansia yang pada penelitian ini terdapat juga pada lanjut usia (old 75-89 tahun) sehingga mempengaruhi dalam proses pengaruh intervensi balance exercise. Sedangkan pada tahap pre intervensi didapatkan hasil kekuatan dengan jumlah responden $(n=31)$ lansia, dimana sebelumnya kekuatan otot sedikit atau skala 2 ada 7 responden atau 22.6\% (Arifal \& Kharisma, 2018). Hal ini diakibatkan lansia mengalami penurunan pada sistem muskuloskeletal. Salah satu diantaranya adalah penurunan kekuatan otot yang disebabkan oleh penurunan massa otot (atrofi otot). Sel otot yang mati digantikan oleh jaringan ikat dan lemak. Kekuatan atau jumlah daya yang dihasilkan oleh otot menurun dengan bertambahnya usia. Kekuatan otot ekstermitas bawah berkurang sebesar $40 \%$ anatara usia 30 sampai 80 tahun. Perubahan gaya hidup dan penurunan penggunaan sistem neuromuskular adalah penyebab utama untuk kehilangan kekuatan otot (Arifal \& Kharisma, 2018).

Hasil Analisa pada post intervensi dari penelitian diketahui sebesar 3,62\%. Hasil tersebut meliputi skala kekuatan otot 1: sedikit (1 lansia) dan kekuatan otot 5: normal (3 lansia). Hasil tersebut mengindikasikan adanya peningkatan pada kekuatan otot. Kekuatan otot pada responden mengalami peningkatan dikarenakan telah mendapatkan intervensi balance exercise, pada lansia yang kekuatan ototnya menjadi lebih baik karena dipengaruhi oleh skala kekuatan otot sebelumnya. Diketahui bahwa skala otot sebelumnya adalah buruk (4 lansia), dan sedang (4 lansia. Skala kekuatan otot diketahui dapat berpotensi menjadi baik bahkan menjadi normal dari skala sebelum diberikan intervensi.

Pada penelitian sebelumnya dengan jumlah responden $(n)=31$ lansia, diketahui skala kekuatan otot 
responden dengan skala sedikit atau skala 2 terdapat sebanyak 7 responden $(22,6 \%)$ dan setelah diberikan intervensi balance exercise berkurang jumlahnya menjadi 1 responden $(3,2 \%)$. untuk skala kekuatan otot baik atau skala 5 sebelumnya hanya 2 responden (6.2\%) setelah diberikan intervensi balance exercise menjadi 7 responden atau $(22.6 \%)$. Artinya hampir sebagian lansia memiliki skala kekuatan otot 3 dan kekuatan otot 4. Setelah diberikan balance exercise tingkat kekuatan otot pada lansia mengalami peningkatan (Arifal \& Kharisma, 2018).

Penurunan fungsi yang nyata pada lansia adalah penurunan masa otot atau atropi. Penurunan masa otot ini merupakan faktor penting yang mengakibatkan penurunan kekuatan otot dan daya tahan otot. Kekuatan otot adalah kemampuan otot atau kelompok otot untuk menghasilkan gaya maksimal. Daya tahan otot adalah kemampuan otot untuk menghasilkan gaya pada waktu dan kecepatan yang spesifik. Kekuatan otot dan daya tahan otot akan menurun pada proses penuaan dengan daya tahan otot penurunannya lebih besar dari kekuatan otot (Utomo, 2016) (Budi, 2016). Perubahan yang akan ditimbulkan jika kekuatan otot diantaranya perubahan fisiologis. Perubahan fisiologis yang timbul akibat pasca stroke yang mengalami penurunan kekuatan otot diantaranya terjadi penurunan kemampuan mempertahankan keseimbangan tubuh, hambatan dalam gerak duduk ke posisi berdiri, meningkatkan resiko jatuh dan perubahan postur tubuh. Dari beberapa masalah pasca stroke yang sering dikeluhkan pasien adalah kesulitan dalam melakukan aktifitasnya tersebut sehingga penderita pasca stroke cenderung akan ketergantungan terhadap orang lain. Menurut Smith (2008) peningkatan fungsi sensomotorik pada pasien stroke secara signifikan berhubungan dengan peningkatan kapasitas latihan (exercise). Exercise aktif pada pasien stroke akan memberikan pengaruh peningkatan fungsi dari motorik. Penelitian ini juga dibuktikan oleh Arifal dan Kharisma (2018) bahwa setelah diberikan Balance Exercise tingkat kekuatan otot pada lansia mengalami peningkatan

\section{KESIMPULAN}

Terdapat perbedaan yang signifikan rata-rata skala kekuatan otot pada pengukuran pre intervensi balance exercise dan post intervensi balance exercise (nilai $\mathrm{p}=0.000$ ). hasil tersebut mengindikasikan bahwa latihan balance exercise dapat menyebabkan terjadinya peningkatan kondisi kekuatan otot menjadi lebih baik dari sebelumnya

Lansia disarankan untuk mengikuti latihan balance exercise agar kekuatan otot dapat dipertahankan kestabilannya. Diharapkan bagi peneliti selanjutnya dapat menambah variabel yang sudah ada dengan variabel baru mengenai reaksi emosional menggunakan kuisioner DASS agar dapat diketahui mana yang lebih efektif

\section{REFERENSI}

Arianti, D., Novera, M., \& Restipa, L. (2019). Pengaruh Discharge Planning dengan Pendekatan Family Centered Nursing terhadap Kualitas Hidup Pasien Stroke. Jurnal Keperawatan Abdurrab, 2(2), 11-18.

Arifal, A., \& Kharisma, P. (2018). Pengaruh Balance Exercise Terhadap Kekuatan Otot pada Lansia di Desa German Kecamatan Sugio Kabupaten Lamongan 2018. Surya, 10(2), 40-45.

Badan Penelitian dan Pengembangan Kesehatan Kementerian Kesehatan RI. (2018). Laporan Riset Kesehatan Dasar (Riskesdas) tahun 2018. Jakarta.

Costa, M. T. S., Vieira, L. P., de Oliveira Barbosa, E., Oliveira, L. M., Maillot, P., Vaghetti, C. A. O., ... Monteiro-Junior, R. S. (2019). Virtual reality-based exercise with exergames as medicine in different contexts: A short review. Clinical Practice and Epidemiology in Mental Health: CP \& EMH, 15, 15.

Dharmojo. (2011). Geriatri (Ilmu Kesehatan Usia Lanjut). Jakarta: Balai FKUI

Haryani, D., Fatmawati, V., \& Imron, M. A. (2016). Pengaruh Core Stability Exercise dan Balance Board Exercise Terhadap Keseimbangan Pada Mahasiswa Universitas 'Aisyiyah Yogyakarta. Retrieved from http://digilib2.unisayogya.ac.id/handle/123456789/2063

Goldstein, L.B., Adams, R., Alberts,M.J., Appel, L.J., et al. 2006. Primary Prevention of Ischemic Stroke: A Guideline From the American Heart Association/American Stroke Association Stroke Counsil. Stroke.37:1583-1633

Mahendra, \& Rachmawati, Evi, . (2014). Mengatasi Stroke dengan Tanaman Obat. Jakarta: Niaga Swadaya.

Noor, M. A. (2018). Characteristics Of Fatigue Post Stroke Patient's. NURSCOPE: Jurnal Penelitian Dan Pemikiran Ilmiah Keperawatan, 4(1), 55-60.

Pudjiastuti, Sri surini, Budi utomo. (2003). Fisioterapi pada lansia, EGC, Jakarta 
Ramdani, M. L. (2018). Karakteristik dan periode kekambuhan stroke pada pasien dengan stroke berulang di Rumah Sakit Margono Soekardjo Purwokerto Kabupaten Banyumas. Jurnal Keperawatan Muhammadiyah, 3(1).

Sari, I. P. (2016). Stroke Berulang pada Penderita Pasca Stroke. Jurnal Akademika Baiturrhim, 5(2), 7-14. Retrieved from http://stikba.ac.id

Smith, Gerald, V. (2008) "Task-oriented" Exercise Improves Hamstring Strenght and Spastic Reflexes in Chronic Stroke patients". Stroke ahajournal, 2112-2118

Sufiya, Z., Herawati, I., \& Fis, S. (2017). Pengaruh Core Stability Exercises Dengan Metode Bobath Terhadap Keseimbangan Pada Pasien Stroke Di Poli Irm Rsud Salatiga. Universitas Muhammadiyah Surakarta.

Utomo, B. (2016). Hubungan Antara Kekuatan Otot dan Daya Tahan Otot Anggota Gerak Bawah Dengan Kemampuan Fungsional. Universitas Sebelas Maret.

Watila, M.M., Nyandaiti, Y. W., Bwala, S. A., Ibrahim, A. (2010). "Gender Variation Risk Factors and Clinical Presentation of Acute Stroke", Journal of Neuroscience and Behavioural Health, 3(3), 38-43.

Wayunah, W., \& Saefulloh, M. (2017). Analisis Faktor Yang Berhubungan Dengan Kejadian Stroke Di Rsud Indramayu. Jurnal Pendidikan Keperawatan Indonesia, 2(2), 65-76.

Widarti, R., \& Triyono, E. (2018). Pemberian Ankle Strategy Exercise Pada Lansia Terhadap Keseimbangan Dinamis. Gaster, 16(1), 83-93.

Zhang, Y., Chapman, A.-M., Plested, M., Jackson, D., \& Purroy, F. (2012). The incidence, prevalence, and mortality of stroke in France, Germany, Italy, Spain, the UK, and the US: a literature review. Stroke Research and Treatment, 2012. 